\title{
PERAN PROGRAM MAGANG JEPANG BAGI PETANI MUDA DALAM MEREGENERASI PETANI INDONESIA
}

\section{THE ROLE OF THE JAPANESE INTERNSHIP PROGRAM FOR YOUNG FARMERS IN REGENERATING INDONESIAN FARMERS}

\author{
Ahmad Syariful Jamil ${ }^{1}$, Resti Prastika Destiarni ${ }^{* 2}$ \\ ${ }^{1}$ Balai Pelatihan Pertanian Jambi, Jl. Jambi-Palembang Km. 16, Muaro Jambi, Jambi \\ ${ }^{2}$ Departemen Agribisnis, Fakultas Pertanian, Universitas Trunojoyo Madura \\ *E-mail: resti.destiarni@trunojoyo.ac.id
}

(Diterima 27-05-2021; Disetujui 05-07-2021)

\begin{abstract}
ABSTRAK
Permasalahan masa depan sektor pertanian Indonesia, tidak hanya sebatas pada stagnasi produksi komoditas pertanian, namun juga regenerasi petani muda Indonesia. Sektor pertanian mengalami penuaan tenaga kerja, dimana sebagian besar tenaga kerja sektor pertanian di dominasi oleh petani berusia lanjut. Salah satu upaya pemerintah dalam mengatasi permasalahan tersebut adalah dikeluarkannya Program Magang Jepang bagi Petani Muda. Oleh karena itu, penelitian ini bertujuan untuk menganalisis peran program tersebut dalam meregenerasi petani Indonesia. Sebanyak 50 orang alumni program yang tergabung dalam Ikatan Alumni Magang Jepang dijadikan sebagai responden. Penetapan responden dilakukan berdasarkan purposive sampling, dengan pertimbangan jarak tempuh. Pendekatan analisis deskriptif kualitatif digunakan dalam rangka menjawab tujuan penelitian. Hasil penelitian menunjukkan bahwa seluruh alumni responden melanjutkan usaha di bidang pertanian setelah kembali ke Indonesia. Dari sisi pendapatan usaha, terjadi peningkatan pendapatan usaha sebelum dan sesudah alumni dari Jepang. Selain itu, terjadi peningkatan jumlah karyawan yang dipekerjakan oleh alumni responden. Hal ini mengindikasikan adanya upaya yang dilakukan oleh alumni dalam rangka memberdayakan masyarakat sekitar. Dengan demikian, program magang Jepang telah memberikan kontribusi positif terhadap upaya regenerasi petani di sektor pertanian. Dalam rangka memberikan masukan yang komprehensif diperlukan penelitian lanjutan untuk menganalisis dampak program tersebut terhadap tingkat regenerasi petani secara kuantitatif.
\end{abstract}

Kata kunci: Petani muda, program magang Jepang, regenerasi petani

\section{ABSTRACT}

Future problems in the Indonesian agricultural sektor are not only limited to the stagnation of agricultural commodity production, but also the regeneration of young Indonesian farmers. The agricultural sektor is experiencing an aging workforce, where most of the agricultural sektor workforce is dominated by elderly farmers. One of the government's efforts to overcome this problem is the issuance of the Japanese Apprenticeship Program for Young Farmers. Therefore, this study aims to analyze the role of the program in regenerating Indonesian farmers. As many as 50 program alumni who are members of the Japan Apprenticeship Alumni Association were used as respondents. Determination of respondents based on purposive sampling, with consideration of the distance. The qualitative descriptive analysis approach was used in order to answer the research objectives. The results showed that all of the respondents' alumni continued their business in agriculture after returning to Indonesia. In terms of operating income, there was an increase in operating income before and after alumni from Japan. In addition, there has been an increase in the number of employees employed by the respondent's alumni. This indicates an effort made by alumni in order to empower the surrounding community. Thus, the Japanese apprenticeship program has made a positive contribution to efforts to regenerate farmers in the agricultural 


\section{PERAN PROGRAM MAGANG JEPANG BAGI PETANI MUDA \\ DALAM MEREGENERASI PETANI INDONESIA \\ Ahmad Syariful Jamil, Resti Prastika Destiarni}

sektor. In order to provide comprehensive input, further research is needed to quantitatively analyze the impact of the program on the regeneration rate of farmers.

Keywords: young farmer, Japan internship program, farmer regeneration

\section{PENDAHULUAN}

Sumber daya manusia merupakan salah satu unsur penting dalam penggerak sebuah bidang usaha (Elisa; Efendi, M.R.M; Sari, 2014) tak terkecuali pada bidang pertanian. Tanpa adanya sumber daya manusia yang berkompeten maka akan sulit segala kegiatan usaha dapat terlaksana dengan baik. Selain itu, dalam membentuk sumber daya manusia yang cakap, terampil, dan mampu beradaptasi dalam segala kondisi bukanlah hal yang mudah. Dalam perkembangan dunia yang semakin maju, dengan adanya kemajuan teknologi dan terbukanya persaingan secara global, maka setiap bidang usaha dituntut untuk dapat meningkatkan kompetensi dari sumber daya manusia yang dimilikinya (Ahyakudin et al., 2019). Hal tersebut juga berlaku pada bidang pertanian. Bidang pertanian tidak hanya berhubungan terkait pemenuhan kebutuhan pangan, pencapaian ketahanan dan kemandirian pangan, namun juga keberlanjutan pada sumber daya manusia yang berkompeten. Petani sebagai sumber daya manusia utama pada bidang pertanian merupakan suatu masalah yang eksplisit atau tak kasat mata (LIPI, 2018).
Dapat dibayangkan bagaimana keberlanjutan bidang pertanian di Indonesia apabila tidak ada lagi generasi penerus para petanin yang telah berusia lanjut sehingga ada upaya yang dilakukan oleh pemerintah demi menjaga keberlanjutan pengembangan sumber daya manusia di bidang pertanian yaitu salah satunya dengan program magang petani ke Jepang.

Program pengiriman petani muda Indonesia untuk magang ke Jepang merupakan kegiatan rutin tahunan yang dilakukan oleh Badan Penyuluhan dan Pengembangan Sumber Daya Manusia Pertanian (BPPSDMP) Kementerian Pertanian. Kegiatan ini merupakan salah satu upaya untuk mendongkrak kembali minat generasi muda terhadap sektor pertanian di Indonesia sehingga .diharapkan kegiatan pemagangan ini akan memberikan dampak bagi pelakunya berupa remintansi. Remitansi yang diperoleh dapat berupa uang atau harta benda dan remitansi sosial dalam bentuk ide-ide atau ilmu pengetahuan, nilai-nilai, dan perilaku. Remitansi sosial yang diterima oleh para petani muda tersebut merupakan modal (capital) yang 
merupakan potensi aset bagi pembangunan daerah asalnya. Program yang telah dilaksanakan sejak tahun 1984 ini diharapkan akan terus menciptakan pionir usahawan muda tani yang mampu mentransformasikan ilmu pengetahuan yang didapat semasa magang kepada lingkungan sekitarnya.

Program tersebut merupakan upaya dari pemerintah karena berdasarkan data BPS diketahui bahwa terdapat penurunan penyerapan tenaga kerja pada bidang pertanian. Suyanto (2017) dalam (LIPI, 2018) menyatakan bahwa terjadi penurunan minat pada generasi muda untuk bekerja di bidang pertanian yang mana para generasi tersebut menganggap bahwa petanin identik sengan keterbelakangan, kemiskinan, dan ketidaksejahteraan. Pada daerah yang menjadi lumbung pangan nasional di Indonesia juga tidak terlepas dari masalah tersebut karena para anak muda usia produktif 15-23 tahun lebih memilih untuk merantau ke kota dan bekerja sebagai buruh pabrik, pegawai negeri, wiraswasta, ataupun pegawai swasta serta di bidang pekerjaan lain selain bidang pertanian terutama berkaitan dengan budidaya. Munculnya anggapan terkait kondisi petani tersebut pada dasarnya tidak terlepas dari sifat konvensional petani usia lanjut sehingga membuat kehidupan petani tersebut masih jauh dari sejahtera.

Tujuan adanya program pemagangan ke Jepang yang dicanangkan oleh pemerintah melalui Kementerian Pertanian salah satunya adalah untuk meningkatkan minat generasi muda untuk kembali menekuni sektor pertanian. Capaian dari program ini adalah untuk melahirkan pengusaha di sektor pangan dan mendorong tumbuhnya generasi muda yang bergerak di sektor dan subsektor pertanian. Dengan pentingnya program pemagangan ke Jepang ini bagi peningkatan kompetensi sumber daya manusia di bidang pertanian, perlu adanya kajian terkait peran program ini secara nyata bagi petani. Penelitian ini akan mengkaji secara deskriptif kualitatif terkait program pemerintah dalam meregenerasi petani dan peran program magang dalam kaitannya meregenrasi petani sebagai salah satu program unggulan pemerintah. Diharapkan dengan adanya kajian ini dapat diperoleh gambaran bagaimana pemerintah melakukan upaya dalam mendukung regenarsi petani sehingga bidang pertanian tetap maju dan tidak ditinggalkan, namun juga dapat berkembang seiring dengan kemajuan 
jaman. Selain itu, dapat pula menjadi kajian bagaimana peran program magang ke Jepang bagi peningkatan kompetensi dan kemampuan petani baik secara ekonomi maupun sosial.

\section{METODE PENELITIAN}

Penelitian ini dilaksanakan dari Bulan September 2020 hingga Maret 2021. Metode survery digunakan dalam rangka menjawab tujuan penelitian dengan memusatkan pada pemecahan permasalahan aktual dalam upaya regenerasi petani di Indonesia. Sebanyak 50 orang alumni program yang tergabung dalam Ikatan Alumni Magang Jepang dijadikan sebagai responden. Penentuan responden dilakukan menggunakan purposive sampling dengan pertimbangan penyebaran responden dalam suatu wilayah. Responden tersebut seluruhnya berasal dari Provinsi Jawa Timur. Data primer dikumpulkan melalui wawancara dengan panduan menggunakan instrumen penelitian. Instrumen penelitian yang digunakan berupa kuesioner dan panduan (guidance) wawancara. Sementara itu, data sekunder dikumpulkan melalui studi literatur terhadap informasi yang relevan terhadap penelitian ini. Kedua data tersebut selanjutnya dilakukan analisis menggunakan pendekatan deskriptif.

\section{HASIL DAN PEMBAHASAN}

\section{Program Pemerintah dalam Meregenerasi Petani di Indonesia}

Permasalahan terkait penurunan jumlah tenaga kerja muda di sektor pertanian secara umum juga terjadi pada negara-negara lainnya. Fenomena aging farmer dan menurunnya jumlah tenaga kerja muda pertanian juga terjadi di Amerika, Uni Eropa, Korea, dan negara lainnya (Susilowati, 2016). Hal ini umumnya disebabkan adanya perubahan struktur ekonomi nasional dari sektor pertanian ke sektor non pertanian seperti industri dan jasa. Adanya perubahan struktur tersebut memaksa sektor pertanian menjadi sektor termarjinalkan. Salah satu bukti adanya marjinalisasi terhadap sektor pertanian adalah adanya fenomena keengganan petani muda untuk bekerja sebagai petani. Turunnya minat petani muda tersebut umumnya disebabkan rendahnya pendapatan yang didapatkan oleh tenaga kerja sektor pertanian (Arvianti et al., 2019). Selain itu, pendapatan orang tua dari hasil usahatani juga mempengaruhi minat pemuda untuk berkenginan atau meneruskan usahatani keluarga (Arimbawa \& Rustariyuni, 2018).

Turunnya minat pemuda untuk bekerja di sektor pertanian apabila tidak segera ditangani dapat menyebabkan 
rendahnya tingkat produktivitas. Kementerian Pertanian sebagai leading sector telah melakukan berbagai upaya dalam rangka memecahkan persoalan tersebut. Salah satu alternatif solusi beberapa kebijakan dalam bentuk program telah diimplementasikan oleh Kementerian Pertanian. Beberapa program utama dalam meregenerasi petani yaitu Program Pertumbuhan Wirausaha Muda Pertanian (PWMP), Duta Petani Milenial (DPM)/ Duta Petani Andalan (DPA), dan Program Magang Jepang bagi Petani Muda.

Program Penumbuhan Wirausaha Muda Pertanian (PWMP) pada awalnya diinisiasi pada tahun 2016 dengan melibatkan delapan perguruan tinggi mitra, enam Polbangtan dan tiga SMK Pembangunan Pertanian. Program ini diimplementasikan dengan memberikan modal usaha dalam empat tahap selama tiga tahun yang dibagi menjadi tahap penyadaran di tahun pertama, tahun kedua untuk pengembangan dan tahun ketiga untuk tahap kemandirian. Pemberian modal menggunakan anggaran mencapai Rp11.900.000.000,-. Modal tersebut diberikan kepada setiap kelompok masing-masing sebesar Rp15.000.000 untuk pelajar dan Rp35.000.000,- (Novanda, 2017). Sejak tiga tahun diinsiasi dari 2016, program ini telah menghasilkan 1.013 kelompok.

Salah satu program regerasi petani yang telah dibentuk oleh pemerintah yaitu Duta Petani Milenial (DPM). Sama halnya dengan PWMP, program DPM merupakan bentuk upaya mempercepat regenerasi petani di wilayah Indonesia. Program ini dilakukan dengan melakukan seleksi baik kepada calon DPM dan DPA dari masing-masing provinsi. Penetapan DPM dan DPA selanjutnya disahkan melalui Keputusan Kepala Badan Penyuluhan dan Pengembangan Sumber Daya Manusia Pertanian (BPPSDMP). Pada tahun 2020, Kementerian Pertanian telam memiliki 67 DPM/DPA yang tersebar di seluruh provinsi Indonesia. DPM dan DPA tersebut secara umum memiliki peran mendukung dan menginspirasi pemuda dalam bekerja di sektor pertanian.

Diantara kedua program yang telah dijelaskan, Program Magang Jepang bagi Petani Muda merupakan program regenerasi petani yang telah berlangsung cukup lama yaitu sejak 1984. Tujuan dari program ini adalah untuk mencetak wirausaha pertanian melalui penyediaan pengalaman terkait dengan sistem pertanian di Jepang (Jamil et al 2021 dalam ijsser). Petani muda yang lulus 
seleksi nasional akan diberangkankan untuk magang di Jepang dengan bidang pertanian tertentu. Sejak dibentuk tahun 1984 hingga 2018, program ini telah meluluskan wirausaha pertanian sebanyak 1333 orang yang teserbar di seluruh wilayah Indonesia.

Melalui berbagai upaya tersebut diharapkan secara perlahan dapat mampu mendorong regenerasi pemuda tani secara nasional. Terlebih lagi bagi program magang jepang yang relatif sudah berjalan lama. Pemuda tani yang telah kembali ke Indonesia dapat menerapkan pengalaman yang telah diperoleh selama melakukan kegiatan pertanian di Jepang.

\section{Peran Program Magang Jepang dalam Meregenerasi Petani Indonesia}

Pada dasarnya regenerasi merupakan pewarisan usaha pertanian (Leonard et al 2017). Regenerasi petani juga dapat diartikan sebagai bentuk penciptaan atau pembentukan tenaga kerja yang berminat bekerja di sektor produksi pertanian. Anwarudin et al., (2020) menyatakan bahwa regenerasi dapat terjadi dengan masuknya anggota keluarga atau pendatang baru secara professional ke dalam usaha pertanian. Proses regenerasi ini menjadi suatu solusi ditengah adanya maslah penuaan petani dan tidak produktifnya sektor pertanian.

Berdasarkan pengertian regenerasi, program magang Jepang bagi petani muda secara umum telah mendukung regenerasi petani muda di Indonesia. Bentuk dukungan tersebut tidak hanya dalam dimensi kuantitas melainkan juga dimensi kualitas. Secara kuantitas dukungan regenerasi dapat dicerminkan dari hasil penelitian yang menunjukkan bahwa seluruh alumni responden yang tergabung dalam Ikatan Magang Jepang (IKAMAJA) melanjutkan usaha di bidang pertanian setelah kembali ke Indonesia. Hal ini menunjukkan bahwa berbekal pengetahuan yang didapatkan dapat mendukung mereka untuk memulai mengaplikasikannya dalam usaha pertanian. Selain itu, adanya program magang jepang juga turut meningkatkan jumlah karyawan, dimana jumlah karyawan rata-rata yang dimiliki oleh responden sebelum dan sesudah masingmasing sebesar 2 orang dan 4 orang. Hal ini mengindikasikan adanya upaya yang dilakukan oleh alumni dalam rangka memberdayakan masyarakat sekitar.

Dari dimensi kualitas, program magang baik secara tidak langsung juga turut mendukung regenerasi petani. Bentuk dukungannya merupakan 
perubahan mental, sikap, pengetahuan dan perilaku dari petani pasca magang atau anggota IKAMAJA. Kresna (2018) menambahkan bahwa eksternalitas yang diperoleh para petani muda Indonesia pasca magang di Jepang adalah peningkatan etos kerja, kemampuan penguasaan dalam menggunakan alat usahatani modern, kemampuan manajemen produksi tani, dan kemampuan manajemen pemasaran hasil pascapanen. Namun dari berbagai kemampuan yang didapatkan selama magang, perubahan sikap merupakan yang paling dapat mereka terapkan untuk menjalankan kegiatan usahatani di Indonesia. Hal ini dibuktikan dari hasil penelitian yang menunjukkan bahwa 92\% responden menyatakan etos kerja; motivasi; disiplin; kemampuan bernegosisasi dan pemasaran; serta kerja keras adalah aspek yang paling dapat diterapkan pasca magang. Mereka berpendapat bahwa adanya gap teknologi yang cukup lebar antara sistem produksi dua negara menyebabkan kemampuan teknis belum sepenuhnya dapat diterapkan di Indonesia. Perbedaan budaya juga menjadi alasan adanya hambatan implementasi kemampuan teknis yang mereka dapatkan.
Peran program magang jepang dalam meregenerasi petani juga dapat dicerminkan dari faktor keberlanjutan usaha. Hasil penelitian menunjukkan bahwa sebagian besar responden rata-rata memiliki waktu jeda sekitar 1.04 tahun untuk memulai usaha setelah kembali ke Indonesia. Selain itu, responden umumnya (54\%) mengganti bidang yang diusahakan antara sebelum dan sesudah kembali dari Jepang. Kondisi ini umumnya disebabkan adanya perubahan lingkungan seperti harga tidak stabil, iklim investasi tidak menantu dan faktor keinginan diri sendiri. Berdasarkan hasil penelitian ditemukan terjadi peningkatan skala usaha sebelum dan sesudah program. Kondisi ini dicerminkan dari perubahan tingkat pendapatan, dimana secara rata-rata masing-masing sebesar Rp9.317.222/tahun dan Rp22.998.134/ tahun.

Berbagai peran yang telah dilakukan dapat memiliki dampak multiplier yang lebih besar lagi apabila alumni program dapat menjadi seorang wirausaha pertanian. Menurut Yulianto \& Riskianingrum (2015), keberhasilan dari program magang dengan pengetahuan yang dimiliki oleh pelakunya tidak hanya dinilai dari konsistensi mereka untuk tetap bekerja pada sektor pertanian 
semata, tetapi juga seberapa besar pengetahuan mereka bermanfaat untuk masyarakat di desanya dalam membangun perekonomian desa melalui wirausaha pertanian. Kehadiran wirausaha tentu akan memberi pengaruh terhadap kemajuan perekonomian masyarakat sekitar (Mutiarasari, 2018).

\section{KESIMPULAN DAN SARAN}

Program pengiriman petani muda Indonesia untuk magang ke Jepang merupakan kegiatan rutin tahunan yang dilakukan oleh Badan Penyuluhan dan Pengembangan Sumber Daya Manusia Pertanian (BPPSDMP) Kementerian Pertanian. Kegiatan ini merupakan salah satu upaya untuk mendongkrak kembali minat generasi muda terhadap sektor pertanian di Indonesia sehingga .diharapkan kegiatan pemagangan ini akan memberikan dampak bagi pelakunya berupa remintansi. Program tersebut merupakan upaya dari pemerintah karena penurunan penyerapan tenaga kerja pada bidang pertanian. Penurunan minat pada generasi muda untuk bekerja di bidang pertanian yang mana para generasi tersebut menganggap bahwa petanin identik sengan keterbelakangan, kemiskinan, dan ketidaksejahteraan.
Kementerian Pertanian sebagai leading sector telah melakukan berbagai upaya dalam rangka memecahkan persoalan tersebut. Salah satu alternatif solusi beberapa kebijakan dalam bentuk program telah diimplementasikan oleh Kementerian Pertanian. Beberapa program utama dalam meregenerasi petani yaitu Program Pertumbuhan Wirausaha Muda Pertanian (PWMP), Duta Petani Milenial (DPM)/ Duta Petani Andalan (DPA), dan Program Magang Jepang bagi Petani Muda.

Diantara program yang ada, Program Magang Jepang bagi Petani Muda merupakan program regenerasi petani yang telah berlangsung cukup lama yaitu sejak 1984. Petani muda yang lulus seleksi nasional akan diberangkankan untuk magang di Jepang dengan bidang pertanian tertentu. Sejak dibentuk tahun 1984 hingga 2018, program ini telah meluluskan wirausaha pertanian sebanyak 1.333 orang yang teserbar di seluruh wilayah Indonesia. Melalui berbagai upaya tersebut diharapkan secara perlahan dapat mampu mendorong regenerasi pemuda tani secara nasional. Terlebih lagi bagi program magang jepang yang relatif sudah berjalan lama. Pemuda tani yang telah kembali ke Indonesia dapat 
menerapkan pengalaman yang telah diperoleh selama melakukan kegiatan pertanian di Jepang.

Secara kuantitas dukungan regenerasi dapat dicerminkan dari hasil penelitian yang menunjukkan bahwa seluruh alumni responden yang tergabung dalam Ikatan Magang Jepang (IKAMAJA) melanjutkan usaha di bidang pertanian setelah kembali ke Indonesia. Hal ini menunjukkan bahwa berbekal pengetahuan yang didapatkan dapat mendukung mereka untuk memulai mengaplikasikannya dalam usaha pertanian. Dari dimensi kualitas, program magang baik secara tidak langsung juga turut mendukung regenerasi petani. Bentuk dukungannya merupakan perubahan mental, sikap, pengetahuan dan perilaku dari petani pasca magang atau anggota IKAMAJA. Berbagai peran yang telah dilakukan dapat memiliki dampak multiplier yang lebih besar lagi apabila alumni program dapat menjadi seorang wirausaha pertanian.

\section{UCAPAN TERIMA KASIH}

Penulis mengucapkan terima kasih kepada the Sumitomo Foundation Jepang yang telah memberikan kesempatan dan pendanaan dengan skema Grant for Japan-related Research Projects tahun
2019, sehingga penelitian ini dapat terselesaikan.

\section{DAFTAR PUSTAKA}

Ahyakudin, A., Najib, M. A., \& Haryadi, D. (2019). Peran Pelatihan Dengan Metode On The job Training dan Metode Apprenticeship Untuk meningkatkan Kinerja Karyawan Pada perusahaan Labbaik Chicken Kota Serang. Syi ar Iqtishadi : Journal of Islamic Economics, Finance and Banking, 3(2), 20. https://doi.org/10.35448/jiec.v3i2.6 592

Anwarudin, O., Sumardjo, S., Satria, A., \& Fatchiya, A. (2020). Process and Approach to Farmer Regeneration Through Multi-strategy in Indonesia. Jurnal Penelitian Dan Pengembangan Pertanian, 39(2), 73.

https://doi.org/10.21082/jp3.v39n2. 2020.p73-85

Arimbawa, I. P. E., \& Rustariyuni, S. D. (2018). Respon Anak Petani Meneruskan Usaha Tani Keluarga Di Kecamatan Abiansemal. EJurnal Ekonomi Pembangunan Universitas Udayana, 7(7), 15581586.

Arvianti, E. Y., Masyhuri, M., Waluyati, L. R., \& Darwanto, D. H. (2019). Gambaran Krisis Petani Muda Indonesia. Agriekonomika, 8(2), 168-180. https://doi.org/10.21107/agriekono mika.v8i2.5429

Elisa; Efendi, M.R.M; Sari, N. . (2014). Peranan Pelatihan Dalam Peningkatan Kinerja Karyawan (Studi Kasus Bagian Operasional PT PLN (PERSERO) Pembangkitan Sumatera Selatan Bagian Selatan). Jurnal Orasi Bisnis Edisi Ke-XII, November, 


\section{PERAN PROGRAM MAGANG JEPANG BAGI PETANI MUDA \\ DALAM MEREGENERASI PETANI INDONESIA \\ Ahmad Syariful Jamil, Resti Prastika Destiarni}

92-106.

https://www.jurnal.polsri.ac.id/inde

x.php/admniaga/article/download/5 $28 / 403$

Kresna, M. (2018). Sinergi Pengembangan Wirausaha Muda Tani Melalui Transformasi Pengetahuan Petani Alumni Magang Jepang. In Belajar dari Jepang Transformasi Pengetahuan Alumni Kenshuusei Pertanian Indonesia (pp. 111-130).

LIPI. (2018). Belajar Dari Jepang (Gusnelly \& D. Riskianingrum (eds.); 1st ed.). LIPI Press.

Mutiarasari, A. (2018). Peran Entrepreneur Meningkatkan Pertumbuhan Ekonomi dan Mengurangi Tingkat Pengangguran. Jurnal Prodi Ekonomi Syari'ah, 1(2), 1-114.
Novanda, R. R. (2017). Intensi Wirausaha Sektor Pertanian pada Generasi Muda (Studi Kasus Program Penumbuhan Wirausaha Muda Pertanian). In Sekolah Pascasarjana, Institut Pertanian Bogor.

Susilowati, S. H. (2016). Fenomena Penuaan Petani dan Berkurangnya Tenaga Kerja Muda Serta Implikasinya bagi Kebijakan Pembangunan Pertanian. Forum Penelit. Agroecon., 34(1), 35-55.

Yulianto, B. A., \& Riskianingrum, D. (2015). Kiprah IKAMAJA sebagai Bentuk Transformasi Pengetahuan: Sebuah Penutup. In Belajar dari Jepang Transformasi Pengetahuan Alumni Kenshuusei Pertanian Indonesia (pp. 161-178). 